\title{
Feed Technology Usage In Revenue Rising Of Traditional Beef Cattle Farmin North Dumoga, Bolaang Mongondow Regency
}

\author{
Tilly Flora Desaly Lumy ${ }^{1,3}$, Zaenal Fanani ${ }^{2}$, Budi Hartono ${ }^{2}$, \\ Lefrand Winston Sondakh ${ }^{3}$ \\ ${ }^{I}$ A Doctoral Program Student, Faculty of Animal Husbandry, Brawijaya University \\ ${ }^{2}$ A lectuer at Faculty of Animal Husbandry, Brawijaya University \\ ${ }^{3}$ A lectuer at Faculty of Animal Husbandry, Sam Satulangi University
}

\begin{abstract}
This study aims to analyze the impacts of feedtechnology usage in raising the revenue of beef cattle farmers in North Dumoga Subdistrict, Bolaang Mongondow Regency, North Sulawesi Province. The results of study showed that:(1)Feed technology usage led to increased production costs, but it also led to increased revenue, resulting in increased revenue of household of traditional cattle farmers, (2)Expended labor of respondent farmers after using feed technology was higher than before using feed technology, which seemed different with Chayanov' theory stating that using technology would reduce expended working hours of family in their farming, so it provided leisure time for family members for recreation or other activities. This difference was due to the characteristics of traditional technology or hereditary technology with working time allocation of human labor that was still likely to be higher than advanced technology and intermediate technology, (3)The highest revenue raising of beef cattle farm equal to $18.29 \%$ occurred to the application of simulation usageof feed technology with subsidy policy by the government tocattle farm production cost reduction equal to $25 \%$ onthe economy of traditional beef cattle farmers; and (6) Some policies could improve the production and suppress cost factors sothey could increase the household economy of traditional beef cattle farmers. Some suggestions for policy makers based on the results of this study, it is expected to implement the policiesof(1)feed technology support in the economy of beef cattle farmers, and (2)subsidy of the increase in the number of cattle ownership.
\end{abstract}

\section{Introduction}

Livestock development is an integral part of agricultural development and national development,it is carried out in the direction of public policy of livestock and animal health development, such as increasing cattle population and productivity, and increasinganimal feed production.

One of the current livestock development programs is self-sufficiency in beef/ buffalo and animal feed supply that is safe, healthy, wholesome and halal. Livestock development policy needs to be based on the potential of local resources. The support of government policy is necessary to protect beef cattle farm with all the pro-people policies.

Beef cattle farm by farmers households is still managed traditionally. The development of strategic commodityarea of beef cattle inthe province of North Sulawesi, that is in Bolaang Mongondow shows the same thing.The cattle farm in North Dumoga Subdistrictsis still carried out traditionally.

Success of beef cattle farm, among others, is determined by feed adequacy in term of both quantity and quality (Hartono, 2011). Forage is a major component of the availability of land, and it should be supported by rules and policies. The usage of feed technology will be able to improve the economy of farmers household and will provide exciting opportunities to the development of agriculture, especially environmentally friendly livestock. Technology plays an important role in increasing productivity (Ellitan, 2003).

Feeds used in cattle fattening in the Subdistrict of North Dumoga aregenerally in form of forage, grains, and crop wastes, namely: Australian grass,corn and rice straw, corn cob and grains, and rice bran. Technology of feed given to cattle is a simple technology, i.e. the preparation of concentrateappropriate to local resources availability and given feed supplements and feed additives.

The usage of feed technology has greatly influenced the decisions in the household carrying out production activities, labor and consumption allocation, so it is necessary to conduct research on the relationship between the usage of technology and household decisions in carrying out its activities. This study examines the impacts of feed technology on household economy behavior by looking at how big the changes of production, labor allocation,revenue and household consumption as a result of the usage of feed technology in the research site.

To meet their needs, beef cattle farmersdo not only rely on the cattle farm, but also carry out farming other than beef cattle,farming apart from livestock, and non farming. Therefore, the revenue of farmers in the conceptual framework can be classified into (1)revenue from livestock (beef cattle and non beef 
cattle)(2)income from crop farming both wetland and dryland (3)revenue from nonfarming. Thus, this revenue can be estimated through the production function and measured through the revenue function due to many different types of commodities cultivated by farmers.

In household economy, the households act as producer or consumer. Households allocate their labor to produce output in an effort to increase revenue. The earned revenue is allocated for consumption of both food consumption and non-food consumption.Initially, Chanayov developed a model of households in the context of the allocation of production factors owned by the farming households. Production and consumption decisions in farming households hadrelationships to each other. Chayanov economic model was to maximize utilities with three constraints, namely a) the level of production, b) a minimum revenue level that is acceptable, and c) the maximum number of working days of farmer households.

Basically technological variables affect production decisions, labor allocation, and consumption. The main goal of introducing feed technology is to increase the productivity of cattle farm that is added value of cattle farm and feed cost. By increasing the productivity of cattle farm, it will increase the household revenue and labor absorption.

\section{Formulation of Problems}

Feed has an important role in the productivity of cattle.Animal feedneeds can be met usingforage(as the main feed) and concentrate (as supplement feed) tocarry out production. Feed previously given to beef cattle in North Dumoga in form of grass and agricultural waste, in recent years it has tried using concentrates processed using local materials, and has been given as additional feed. This simple feed technology has led to increased cattle productivity, but it also increases the production cost of cattle farm and influences farmer households. Based on the background and its issues, it is then formulated the problem as follow: How is the impacts offeed technology usage in improving food production and raising the revenue of traditional beef cattle farm.

\section{Research Objectives}

The objective of this study is to analyze the impact of the use of feed technology,labor reductions, subsidyof increasing the number of cattle ownership, subsidyof cattle farm production costs, subsidy of feed consumption expenditure, strategies of increasing the selling price of cattle, subsidy of education and health subsidy that isquite effective in raising the revenue of beef cattle farmers, improving the production output and reducing the cost factors needed in the cattle farm.

\section{Research Methods}

Operational definitions of the variables in this study are:

1.Farmer household economy include revenue,expended labor and consumption that is staple consumption of feed, non feed staple consumption and non staple consumption.

2. Feed technology is the introduction of forage of superior cattle, concentrates andquality feed supplement/ additive.

3. Number of Cattle Ownership (JTS) is the number of cattle owned and raisedby farmers and calculated based on cattle animal unit, that is adult cattle $1 \mathrm{AU}$, cattle cows aged $1-2$ years $0.5 \mathrm{AU}$ and cattle $<1$ year $0.25 \mathrm{AU}$.

4.Expensed Labor in Beef Cattle Farm (CTK)is the expensed working hour on the management work of farming/ beef cattle farm measured in working hours equivalent to adult men working hours (JKSP/ year/ respondent).

5. Number of Animal feeding (KPT) is the amount of forage feed costs, concentrates and additional feed (Rp/year/ respondent)

6. Beef Cattle Production (PS) is the number of cattle sold or still raisedcalculated based on unit of cattle, namely adultcattle $1 \mathrm{AU}$,cattle aged 1-2 years old $0.5 \mathrm{AU}$ and cattle $<1$ years old $0.25 \mathrm{AU}(\mathrm{Rp} / \mathrm{AU} /$ year/ respondent).

7. Acceptance of Beef Cattle Farm(PUST) is the money value of beef cattle that have been sold or are still raised for a year $(\mathrm{Rp} /$ year/ respondent).

8. Production cost of BeefCattle Farm(BPROS)is all costs incurred in the cattle farm for a year,consisting of a variable cost, i.e. cost of feed, labor costs, cost of vaccine and medicine, as well as fixed cost, that is the depreciation of cagecost, equipment costs, cost of cows and calves ( $\mathrm{Rp} /$ year/ respondent).

9. Beef Cattle FarmRevenue(PUS) is the revenue earned by farmer households of the beef cattle farm minus the production cost of cattle farm for a year $(\mathrm{Rp} /$ year/ respondent $)$.

10.Animal Feed Investment (IPT) is the investment cost for the production of fodder cultivation and purchase of concentrate raw materials, as well as additional feed (feed supplement/ additive) $(\mathrm{Rp} /$ year/ respondent).

The research was conducted in the Subdistrict of North Dumoga, BolaangMongondow North Sulawesi Province.The research site was choosen using Multistage Sampling Method, every area level of the research site was using purposive sampling.In this study, survey method was used. This study systematically and factually 
describes the phenomena that exist now and also describes the relationship among phenomena, tests hypotheses, and makes interpretations and obtains the meaning of the phenomenon under study (Sekaran, 2006). Survey method was to take samples of a population using questionnaires. Primary data weredrawn from respondents, while secondary data weredrawn from institutions associated with the research (Singarimbun and Effendi, 1995).

Bolaang Mongondow Regency was chosen to conduct the study on the basis that this regencywas a center for the production of beef cattle and one of the development areas of beef cattle in the province of North Sulawesi. North Dumoga districts was chosen for the study because it wasthe subdistrict with the largest population of cattle and we could find cattle fattening program here.

To analyze the economy model of beef cattle farmer households, a simultaneous equation model was used. For the data analysis, it was arranged in a linear fashion through simultaneous equations which were identified using the easiest technique, that was Indirect Least Square (ILS). If the simultaneous equation was over-identified, then Two Stage Least Square (2SLS)or three Stage Least Square (3SLS) was used.The data processing was carried out using the computer program of Statistical System (SAS).

Production of cattle was allegedly influenced by expended labor of beef cattle farm, farm workers and the number of expenditures for animal feed, which was formulated as follows:

$$
\begin{aligned}
& \text { PS }=\mathbf{f}(\text { CTK, KPT }) \\
& \text { PS }=\mathbf{a}_{0}+\mathbf{a}_{1} \text { CTK }+\mathbf{a}_{2} \text { KPT }+\mathbf{e}_{\mathbf{i}}
\end{aligned}
$$

Hypotesis : $\mathrm{a}_{0}, \mathrm{a}_{1}, \mathrm{a}_{2},>0$

Description:

PS: beef cattle production (Rp/AU/ Year/ Respondent)

CTK:Expended labor of cattle farm (JTS/ year/ respondent)

KPT: Expenditures for animal feed(Rp/ year/ respondent).

The use of family labor was allegedly influenced by the number of cattle ownership, number of productive age family members, which could be formulated as follows:

$$
\begin{aligned}
& \text { CTK }=\mathbf{f}(\mathbf{J T S}, \mathbf{J A G}) \\
& \mathbf{C T K}=\mathbf{b}_{\mathbf{0}}+\mathbf{b}_{\mathbf{1}} \mathbf{J T S}+\mathbf{b}_{\mathbf{2}} \mathbf{J A G}+\mathbf{e}_{\mathbf{i}}
\end{aligned}
$$

Hypotesis : $\mathrm{b}_{0}, \mathrm{~b}_{1}, \mathrm{~b}_{2},>0$

Description:

CTK:Expended labor on cattle farm (JTS/ year/ respondent)

JTS: The number of cattle ownership (AU/ respondent)

JAG: The number of family members of the household (person/ respondent)

Efforts to improve the economy of beef cattle farmer household could be carried out through government policy and the management. The increase of economyhousehold through beef cattle farm could be carried out by increasing the number of cattle ownership,cow pricing policy,and quality of beef cattle. Policies that could be carried out were analyzed by simulation, either single simulation or double simulation (combination).

\section{Results and Discussion}

The household revenues of respondents were sourced from cattle farm revenue and nonfarmingrevenue. The revenue of farming non cattle farm, consisted of rice paddy farmingrevenue and croplands. The household revenue of respondents based on its type as a source of revenue can be seen in Table 1.

Table 1.The Revenue of Respondent Cattle Farmer Household based on the Types of Revenue Sources

\begin{tabular}{llrrr}
\hline \multirow{2}{*}{\begin{tabular}{l} 
Sources of Revenue \\
\cline { 3 - 5 }
\end{tabular}} & \multicolumn{1}{c}{$\begin{array}{c}\text { Total } \\
(\mathrm{Rp} .)\end{array}$} & \multicolumn{1}{c}{$\begin{array}{c}\text { Average } \\
(\mathrm{Rp} .)\end{array}$} & \multicolumn{1}{c}{$\begin{array}{c}\text { Contribution } \\
(\%)\end{array}$} \\
\hline$\Rightarrow$ & Beef Cattle Farm & $392.500 .004,88$ & $6.038 .461,61$ & 18.29 \\
$\Rightarrow \quad$ Farming Non Beef Cattle Farm & $792.090 .750,00$ & $12.186 .011,54$ & 36.91 \\
$\Rightarrow \quad$ Farm Worker & $633.600 .000,00$ & $9.747 .692,31$ & 29.52 \\
$\Rightarrow$ Outside Farming & $328.001 .500,00$ & $5.046 .176,92$ & 15.28 \\
\hline \multicolumn{1}{c}{ Total } & 2.146 .192 .254 .88 & 33.018 .342 .38 & 100.00 \\
\hline
\end{tabular}

Table 1 showed that most contribution of the respondentfarmerhousehold revenue, equal to 36.91 percent, came from farming outside cattle farm. It is due to the respondents were generally farmers cultivating paddy rice as the main farming. Cattle farm revenue contributed to the highest third rank, equal to 18.29 percent, for cattle farm was only as a sideline farming. Agustin and Nurmanaf (2002) and Hartono (2011) explained that the revenue contribution of cattle farmwas still relatively low, less than 30 percent, because it wascarried out traditionally and only as a sideline so not as a primary source of household revenue. 
The revenue of cattle farmwasthe selling of cattle either already sold or still being raised, reduced by overall cost of production. The study showed that cattle farmrevenue of all respondents ranged in from $813,612.50$ to $15,132,981.25 \mathrm{rupiah} /$ year with an average of $6,038,461.6135 \mathrm{rupiah} /$ year. This result was similar to the result of study conducted by Priyanti (2007), amounted to 6,652,682 rupiah/year for crops-cattle integration system and 3,306,542 rupiah/year for non crops-cattle integration system. Although only as sideline farming, cattle farm was able to provideadditional revenue for farmers with an average of 569,529.79 rupiah/ month.

Cattle farm in the research area was previously as a dual-function cattle farm, serving as working cattle and beef cattle.Labor utilization of cattle was in the land cultivation of crop farming in the product transportation of crop farming. Currently, by the shift of labor utilization of cattle farm to utilization of farming mechanization, cattle are no longer used as processing workers of farming land, but as beefcattle farm for commercial purpose.

Cattle farm in the research area was still carried out traditionally, so the technology adopted was still a simple technology. The technology analyzed in this study was the technology of feed, especially feed concentrates and feed supplement/ feed additive used for the cattle owned by farmers.

Cattle farmwas carried out as a beef cattle fattening, so thetraditionalfeeding was switched to feeding that adopted concentrate processing technology as well as provided feed supplement/ additive of industrial production. Concentrates given were concentrates prepared by themselves using raw materials such as corn, rice bran, coconut cake, and other agricultural wastes such as corn straw and rice straw, while the feed supplement/ additive used were multivitamins and probiotics.

The successful development of livestock sub-sector to increase the production was inseparable from the role and utilization of science and technology oflivestock(Kusnadi, 2008). Adoption of technology was an important way to increase the productivity in a variety of production systems,i.e. producers got benefit from the application of technology to reduce production costs, increasing the output from the same input, or keeping the same output from the input reduced. This study compared the calculation of respondents on costs, receiptsand revenues before and after the usage or adoption of feed technology on the cattle farm productivity. It can be seen in Table 2.

Table 2 Cost,Receipts, and Revenue of Cattle Farm without Using Feed Technology or Using Feed Technology

\begin{tabular}{|c|c|c|c|}
\hline & Description & Without Feed Technology & Using Feed Technology \\
\hline \multirow{2}{*}{1} & $\begin{array}{l}\text { Total Cost } \\
\text { (Rp/Year) }\end{array}$ & $1,369,292,947.1$ & $1,778,812,495.1$ \\
\hline & $\begin{array}{l}\text { Average Cost } \\
\text { (Rp/ Year/Respondent) }\end{array}$ & $21,066,045.0$ & $27,366,346.0$ \\
\hline \multirow[t]{2}{*}{2} & $\begin{array}{l}\text { Total Receipts } \\
\text { (Rp/ Year) }\end{array}$ & $1,692,737,500.0$ & $2,171,312,500.0$ \\
\hline & Average Receipts (Rp/ Year /Respondent) & $26,042,115.0$ & $33,404,808.0$ \\
\hline \multirow{2}{*}{$2-1$} & $\begin{array}{l}\text { Total Revenue } \\
\text { (Rp/ Year) }\end{array}$ & $323,444,552.9$ & $392,500,004.9$ \\
\hline & $\begin{array}{l}\text { Average Revenue } \\
\text { (Rp/ Year /Respondent) }\end{array}$ & $4,976,070.0$ & $6,038,462.0$ \\
\hline
\end{tabular}

The results of analysis as shown in Table 2 indicated that by adopting technology,there wasan

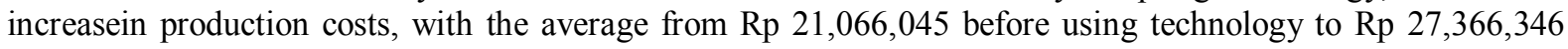
after using feed technology, but there was also an increase in revenue with the average from $\mathrm{Rp} 26,042,115$ before using technology to Rp 33,404,808 after using feed technology, resulting in an increase in revenue from

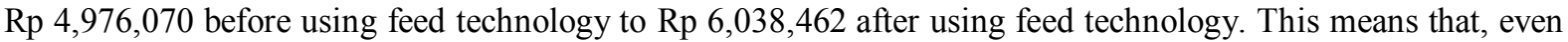
if the use of technology leads to increased cost of production, but it iscoupled with a significant increase in revenueso it earns revenue that is greater than without usingthe feed technology.

Utilization of feed technology aims to improve productivity of cattle and increased revenue, so that farmers using feed technology generate greater additional revenue. The results of data analysis on Cost, Receipts and Revenue of Cattle Farm can be illustrated graphically as shown in Figure 1. 


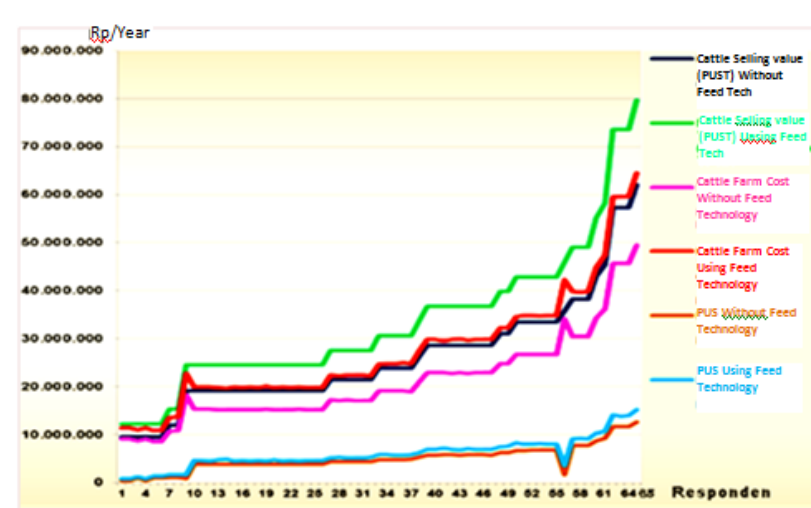

Figure 1TheChartof Comparisonamong Cost, Receipts, and Revenue of Cattle Farm before and after using feed technology (non feed technology)

The research resultsas explained by Sheeded and El Mourid (2005)stated that one of the goals to raise the productivity was producers increasedthe production by increasing inputs. The producers in this study, that were farmers, raise the feed input using concentrate technology to improve the productivity, that was cattle farm revenue, thereby increasing farmers household economy revenue.

Table 3Expended Labor and Revenue of Cattle Farm Before and After Using Feed

\begin{tabular}{|c|c|c|c|}
\hline & Description & Before Feed Technology & After Feed Technology \\
\hline \multirow{2}{*}{1} & $\begin{array}{l}\text { Total Expended Labor } \\
\text { (JTS/Year) }\end{array}$ & 107,591 & 215,182 \\
\hline & $\begin{array}{l}\text { Average Expended Labor } \\
\text { (JTS/ Year/Respondent) }\end{array}$ & 1,655 & 3,310 \\
\hline \multirow{2}{*}{2} & $\begin{array}{l}\text { Total Revenue } \\
\text { (Rp/ Year) }\end{array}$ & $323,444,552.9$ & $392,500,004.9$ \\
\hline & $\begin{array}{l}\text { Average Revenue } \\
(\mathrm{Rp} / \text { Year/Respondent) }\end{array}$ & $4,976,070.0$ & $6,038,462.0$ \\
\hline
\end{tabular}

The results of analysis as shown in Table 3 indicated that the adoption of technology led to an increase in average expended labor from1,655 Labor equivalent to Men (TKSP) before using feed technology to 3,310 Labor equivalent to Men (TKSP) after using feed technology, thereby increasing the cost of wages. Increased expended labor was carried out to improve productivity, i.e. an increase in the average revenuefrom $\mathrm{Rp}$ 4,976,070 before using feed technology to Rp 6,038,462 after using feed technology.

The results of this study indicated that the expended labor of respondent farmers after using feed technology was higher, than before they used feed technology.This study results were similar to the results of study by Wantasen et al,(2012) stating that by using artificial insemination technology, it could improve the expended working time in the beef cattle farm in Minahasa. It seemed that both results of the studieswere in contrast to the theory proposed by Chayanov (1966) in his book entitled The Theory of Peasant Economy, and Haworth and Veal (2004)whose book entitled Work and Leisure as well as Csikszentmihalyi and LeFevre (1989) and Harrison (1975),stating that family cattle farmrelied on the work of their own family members,in which the usage of technology would reduce the family's expended working hours on its farming, thereby providing leisure time for the family members to have recreation or other activities.

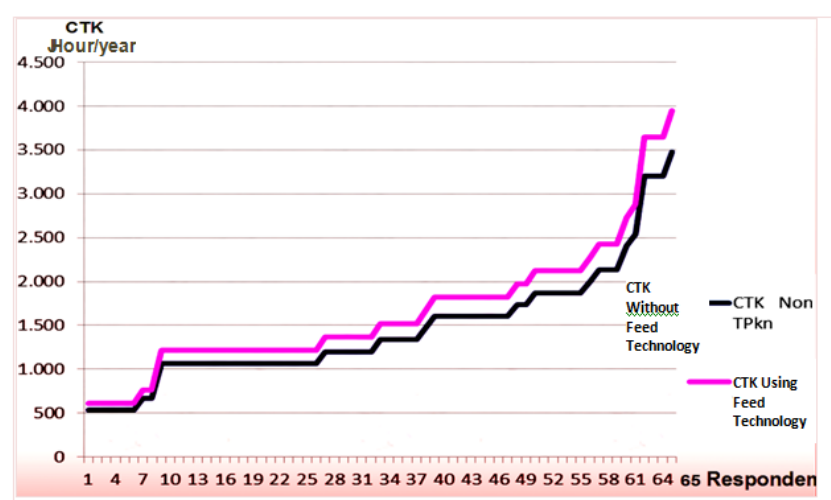

Figure 2.The Differences between Expended Labor Before Using Feed Technology (CTK Without Feed Technology) and After Using Feed Technology (CTK Using Feed Technology) 
The results of this study seemed breaking Chayanov's theory, but actually it was not, because the characteristics of farming particularly technology and job opportunities in Chayanov's area weredifferent with the technology and job opportunities in this research area, in which the technology meant by Chayanov was advanced technology or high-technology or intermediate technology which generally simplified human labor, thereby reducing working time allocation of human labor. Whereas in this study area, beef cattle farmers still used traditional technology or hereditary technology, of which the characteristics of such technologies were likely to use working time allocation of human labor which was still relatively high.

It also occurred because of the availability of family labor havingspare time (leisure) from other farming, paddy rice farming recentlywas applying the technology of agricultural mechanization, that was using tractors in cultivating their fields, so they used the spare time to work and increased the utility, namely the cattle farm productivity and household revenue. These results were in line with Priyanti's study (2007)stating that the impacts of increased expended family labor outside farming resulted in the reallocation of family labor usage in decreased and increased rice farming in the use of labor on cattle farm.

The assumptions of Bernstein (2009), Ellis (1989) and Thilagarathne and Yanagita (1996) stated that households would choose a combination of output and leisure that could maximize utility.Because there were two conditions of farmer households, namely farmer households that hired labor from outside and the householdsthat rentedtheir labor to save on wages and gain wages, it was due to the availability of family labor having free time (leisure) and improvingutilities, i.e. productivity and household revenues.

The usage of technology by farmers' family is presented in Figure 2 (derived from the relationship betweenExpended Labor (CTK, JTS unit/ respondent/year)and the Cattle FarmRevenues (PUS, unit of $\mathrm{Rp} /$ respondent/year.) Figure 2 shows the wider working time compared to family labor' spare time using feed technology, that raise cattle farm revenue so raisingfarmer households' revenue.

The production of beef cattle in this study was beef cattle farm receipts, that was the value of cattle that had been sold or still raised for a year. In Table 4.6, it can be seen the data of the number of and average of beef cattle production, expended labor oncattle farm, and animal feed consumption for a year.

Table 4.6 shows the beef cattle farm receipts generated by all respondents equal to 2,171,312,500.00 rupiah/ year or an average of 33,404,807.69 dollars/ year per respondent. This average production value is quite large, compared to the reports by Priyanti (2010) reporting that the average was only 10,849,812 rupiah/ year for crops-cattle integration systems amounted to 5,767,214 rupiah/ year for non-integration system.

The analysis results of estimation of parameter - equation parameter of Beef Cattle Production (PS) in conjunction with Expended Labor onCattle farm(CTK) and Animal feed Consumption (KPT), show the analysis results of model equation of Beef Cattle Production (PS), as follows:

\section{$P S=69,208+0.3696 C T K+0.0379 K P T$}

The analysis results of Probability $\mathrm{F}<0.05$ mean that simultaneously the variables consisting of Expended Labor onCattle Farm(CTK) and the Animal feeding (KPT) significantly influence Beef Cattle Production (PS).

The results of testing partially using $t$ test show some important things below.

- First.Of the Expended Labor effect onCattle farm(CTK) on Beef Cattle Production (PS), it was obtained $t_{\text {count }}$ $6.30>\mathrm{t}_{\text {table }}$ equal to 1.99 , and Prob $\mathrm{t}$ equal to $(<0.0001)<0.05$. The results of this analysis showed that partially, the Expended Labor onCattle Farm(CTK) affected Beef Cattle Production (PS).

The positive CTK parameter coefficient indicated if the Expended Labor onCattle Farm(CTK)was increased, it would result in increased production of beef cattle (PS). These results as reported by Hartono (2005) and Wantasen et al(2012) stated that the more cattle raised, the more efficient the expended labor.

- Second,Of the consumption/Animal feeding (KPT)effecton Beef Cattle Production value (PS), it was obtained $\mathrm{t}_{\text {count }} 2.96>\mathrm{t}_{\text {table }}$ equal to 1.99 , and Prob $\mathrm{t}$ equal to $0.0043<0.05$. This results partially showed that Animal feeding (KPT) affected the value of Beef Cattle Production (PS).

The parameter coefficient of Livestock Feeding (KPT)that was positive indicated if Animal feeding (KPT)was increased, it would result in increased Production of Beef Cattle (PS), or there were increased additional values of beef cattle. The results of this study showed the rolesof feed in the production, because the feed that had been given had already processed using technology for quality improvement. This means that increasedcattle production will be increased more if it is carried out the increase in the quantity and quality of feed. These results are in line with the Hartono's study (2005)stating that theoretically the strategic point in the increase of production lies in the improvements in the quantity and quality of feed.

The results of analysis of this equation show that partially or simultaneously, the variablesof expended labor oncattle farm(CTK) and consumption/animal feeding (KPT)have positive effects on the production of beef cattle (PS).

Expended labor on cattle farm(CTK)was influenced by the number of cattle ownership (JTS) and the number of family members of household being in productiveage (JAG). Expended labor on cattle farmwasthe 
number of working hours equivalent to men's (JKSP) in feeding and drinking, bathing, and cleaning cages of cattle farm for a year. Table 5.14 shows the average amount of expended labor equal to107,590.75 JKSP or the average of 1,655.24 JKSP for a year or 4.5 JKSP/ day in each respondent. This means that the average number of expended labor per animal unit is equal to $607 \mathrm{JKSP}$ per AU/ year or 1.66 per JKSP AU/ day. The amount of this expended labor is higher than the dairy cattle of the study conducted by Ihsanet al(2001)equal to 138.17 JKSP per AU/ year or Hartono (2010)equal to 68.69 JKSP per AU/ year.The Equation of Expended Labor Model on cattle farm is:

\section{$C T K=712,3820+365,4663 J T S+394,3216 J A G$}

The results showed the value of Prob F equal to $(<0.001)$, and because Prob F $<0.05$, it could be concluded that simultaneously the variables consisting of theNumber of CattleOwnership (JTS) and the Number of Family Members of Household being inProductive Age (JAG) effectedExpended Labor on Cattle farm(CTK). The values of determination coefficient of R Square indicated that $57.20 \%$ of Expended Labor on Cattle farm(CTK)was influenced by the amount of Cattle Ownership (JTS) and the Number of Family Members of Household being inProductive Age (JAG).

The result of testing partially using $t$ test showedseveral things below:

- First on the effect of the number of Cattle Ownership (JTS)on the Expended Labor on Cattle farm(CTK), it was obtained $t_{\text {count }}$ equal to $7.16>t_{\text {table }}$ equal to 1.99 , and Prob $t$ equal to $(<0.0001)<0.05$. These results of analysis showed that partially the number of Cattle Ownership (JTS) effected on Expended Labor on Cattle Farm(CTK). The parameter coefficient of JTS was positive, indicating if the number of Cattle Ownership (JTS)was increased, it would result in increased Expended Labor onCattle farm(CTK).

- Second,on the effects of the number of family members of Household being in productive Age (JAG)onExpended Labor onCattle Farm(CTK), it was obtained $t_{\text {count }}$ equal to $6.64>t_{\text {table }}$ equal to 1.99, and Prob $t$ equal to $(<0.0001)<0.05$. These results showed that partiallythe number of Family Member of Household of Productive Age (JAG) effectedExpended Labor on Cattle farm(CTK). The coefficient parameter of Number of Family Members (JAG)was positive, indicating that the higher the number of household family members of productive age, it could increase the expended labor in the cattle farm.

The results of analysis in this equationshowed that partially or simultaneously the two variables: the number of cattle ownership (JTS) and the number of family members of household being in productive age (JAG)affected positively on the expended labor oncattle farm(CTK).

From these results, it means that the potential laborof family has beenempowered in the cattle farm. It is different with the results of research conducted by Hartono (2005)stating that family's labor potential has not been widely used in dairy cattle farm, and by citing the statements by Irawan et al. (1989)stating that this kind of thing can happen because it can be substituted by hired labor.

The raising of cattle in the study area was still traditional,in whichcattle were only fed by low quality field grass so that the weight of cattle was only 400 grams/head, whereas after intensively raised by feeding them with high quality feed, it couldincrease the weight of cattle to 650 grams/head,meaning that there was an increase of $25 \%$ cattle weight.

The impact of technology usage by $25 \%$ on beef cattle farmers' economy resulted in the highest increase of 26.421\% Expended Labor on Cattle Farm(CTK).The receiptsof beef cattle (PUST) also increased by $22.854 \%$, as well as an increase of $20.206 \%$ Revenue outside PDLT (Land Use under Tress)Farming. These impactsdid not result in the change of Revenues from Beef Cattle Farm (PUS). However, the impacts on the simulation reduced the value of Family Labor(TKK)equal to $-0.028 \%$.

The government policy in the form of direct aid needs serious attention in its distribution to make the aid right on target.From the overall cost of production in the cattle farm, $70 \%$ is the cost of feed,therefore, subsidies are needed for the cost of concentrate feed.The farmers use the concentrate feed made bythemselves, they do not buy the concentrate of plant production due to its expensive price. Based on these problems, it has been tried to simulate the impact of $25 \%$ subsidy of concentrate feed. The results of simulation indicate that $25 \%$ decrease in the cost of production will increase $1.46 \%$ revenueof beef cattle farm.

\section{Conclusion}

1.The majority of revenue of traditional cattle farmerhousehold (81.71 percent)come from farming outside the cattle farm, while the traditional cattle farmrevenue is only equal to 18.29 percent, because the traditional cattle farm is only as a sideline.

2. The usage of feed technology leads to increased production costs, but it also leads to increased revenue, resulting in an increase in revenueof traditional cattle farmerhousehold.

3. Expended labor of respondent farmers is higher after using the feed technology than before using the feed technology, which seems different from Chayanov's theory, stating that the usage of technology will reduce the expended working hours of the family on their farming, thus, it provides leisure or spare time for family 
members to have recreation of other activities. This difference is due to the characteristics of technology and job opportunities in Chayanov's area that are different with the study area here,in which the technology in this research area only uses traditional technology or hereditary technology with the allocation of working time of human labor that is still high.

4. An increase of thehighest beef cattle farm receipt equal to $23.17 \%$ occurs in the application of usagesimulation of feed technology with subsidy policy by the government on production cost reduction of cattle farm by $25 \%$ on traditional beef cattle farmers' economy.

\section{References}

[1]. Bernstein, H., 2009. V.I. Lenin and A.V. Chayanov: looking back, looking forward. The Journal of Peasant Studies 36 (1):55-81.

[2]. Chavas, J.P; R. Petrie and M. Roth., 2005. Farm Household Production Efficiency: Evidence From the Gambia. American Journal of Agricultural Economics. 87 (1):160-179.

[3]. Chayanov, A.V. 1966. The Theory of Peasant Economy, eds. D. Thorner, B. Kerblay and R.E.F. Smith. Richard Irwin for the American Economic Association. Homewood, IL.

[4]. Csikszentmihalyi, M. and J. LeFevre, 1989. Optimal Experience in Work and Leisure. Journal of Personality and Social Psychology 56 (5):815-822.

[5]. Ellis, F., 1989. Peasant Economics, Farm Household and Agrarian Development. Cambridge University Press, New York.

[6]. Ellitan, L., 2003. Resources Role In Increasing Influence Of Technology Producvity. Journal of Management and Entrepreneurship $5(2): 155-170$

[7]. Fanani Z., 1999. Integrated Farming Systems in Dryland Areas (Study On Plant Food with Beef Cattle). Publication Brawijaya University, Malang.

[8]. Harison, M., 1975. Chayanov and the Economics of the Russian Peasantry. Journal of Peasant Studies 2 (4):389-417.

[9]. Hartono, B., 2011. Household Economy Analysis of Beef Cattle Breeders in District Damsol, Donggala, Central Sulawesi Province. J. Tropical Livestock 12 (1):60-70.

[10]. Haryanto, H. 2007. Policy Simulation Model for Economic Development of Dryland Farmers Household-Based Maintenance Goat. Doctoral Dissertation. Brawijaya University of Malang.

[11]. Haworth, J.T., and A. J. Veal, 2004. Work and Leisure. Routledge Inc.. New York and London.

[12]. Hendayana, R and M.H. Togatrop., 2003. Expended Structure Working Time and Income Breeders. Proceedings. National Seminar on Technology of Animal Husbandry and Veterinary, Bogor.

[13]. Hyun, K.N, DW Adams and L.J. Hushak. 1979. Rural Household Saving Behavior in South Korea 1962-76. American Journal of Agricultural Economics, 61 (3):142-152.

[14]. Ihsan, M.N., Z. Fanani and S. Wahyuningsih, 2001. Absorption of Labor Women in Dairy Cattle Enterprises in Malang. Research Journal of Social Sciences 13 (1):14-19.

[15]. Kusnadi, U., 2008. Livestock Technology Innovation in Crop-Livestock Systems Integration to Support Self-Sufficiency Beef. Agricultural Innovation Development 1 (3):189-205.

[16]. Singarimbun and Effendi., 1995. Survey Research Methods. LP3ES. Jakarta.

[17]. Wantasen, E., B. Hartono, H. Nuhfil, and V.V.J. Panelewen, 2012. Household Economic Behavior of Traditional Cattle Farmers in UtilizingArtificial Insemination Technology: A Case Study in Village of Kanonang III, Minahasa Regency of Indonesia. J. Agric. Food. Tech., 2 (8):141-152. 